Meta

Journal des traducteurs

Translators' Journal

\title{
PBL as a New Pedagogical Approach for Translator Education
}

\section{Izumi Inoue}

Volume 50, numéro 4, décembre 2005

Pour une traductologie proactive - Actes

For a Proactive Translatology — Proceedings

Por una traductología proactiva - Actas

URI : https://id.erudit.org/iderudit/019865ar

DOI : https://doi.org/10.7202/019865ar

Aller au sommaire du numéro

Éditeur(s)

Les Presses de l'Université de Montréal

ISSN

0026-0452 (imprimé)

1492-1421 (numérique)

Découvrir la revue

Citer cet article

Inoue, I. (2005). PBL as a New Pedagogical Approach for Translator Education. Meta, 50(4). https://doi.org/10.7202/019865ar

\section{Résumé de l'article}

Actuellement, la formation traditionnelle des traducteurs est dominée par ce que Kiraly (2000) appelle une " approche transmissioniste ». Celle-ci est d'un intérêt limité lorsque les novices doivent appliquer ce qu'ils ont appris aux situations réelles rencontrées dans leur vie professionnelle. Il est donc désormais nécessaire de chercher une nouvelle approche qui nous permette d'aider les novices à développer leurs compétences propres.

L'apprentissage par problèmes (APP) vise à promouvoir chez les novices l'autonomie et l'autoréflexion requises dans la pratique professionnelle face à des problèmes et à des situations difficiles. Si l'APP est de nos jours employé couramment dans ce cadre, aucune tentative notable n'a encore été faite pour introduire cette approche dans le domaine de la formation des traducteurs.

Cet article comporte trois volets principaux. Tout d'abord, nous discuterons des problèmes posés par un enseignement de la traduction centré sur l'enseignant. Puis nous présenterons les avantages de l'APP pour la formation des traducteurs, dans une perspective tant théorique que pratique. Enfin, nous examinerons la faisabilité de l'APP en tant que modèle efficace pour la formation des traducteurs, à partir d'études de cas empiriques.
Ce document est protégé par la loi sur le droit d'auteur. L'utilisation des services d’Érudit (y compris la reproduction) est assujettie à sa politique d'utilisation que vous pouvez consulter en ligne.

https://apropos.erudit.org/fr/usagers/politique-dutilisation/ 


\title{
PBL as a New Pedagogical Approach for Translator Education
}

\author{
IZUMI INOUE \\ Macquarie University, Sydney, Australia \\ iinoue@ozemail.com.au
}

\section{RÉSUMÉ}

Actuellement, la formation traditionnelle des traducteurs est dominée par ce que Kiraly (2000) appelle une « approche transmissioniste ». Celle-ci est d'un intérêt limité lorsque les novices doivent appliquer ce qu'ils ont appris aux situations réelles rencontrées dans leur vie professionnelle. Il est donc désormais nécessaire de chercher une nouvelle approche qui nous permette d'aider les novices à développer leurs compétences propres.

L'apprentissage par problèmes (APP) vise à promouvoir chez les novices l'autonomie et l'autoréflexion requises dans la pratique professionnelle face à des problèmes et à des situations difficiles. Si l'APP est de nos jours employé couramment dans ce cadre, aucune tentative notable n'a encore été faite pour introduire cette approche dans le domaine de la formation des traducteurs.

Cet article comporte trois volets principaux. Tout d'abord, nous discuterons des problèmes posés par un enseignement de la traduction centré sur l'enseignant. Puis nous présenterons les avantages de l'APP pour la formation des traducteurs, dans une perspective tant théorique que pratique. Enfin, nous examinerons la faisabilité de l'APP en tant que modèle efficace pour la formation des traducteurs, à partir d'études de cas empiriques.

\footnotetext{
ABSTRACT

It appears that current mainstream translator education is dominated by what Kiraly (2000) calls a
} 
“transmissionist approach'. This approach is of limited benefit when the novices must apply what they have learnt to real situations that they will encounter as professionals. Thus, it can be said that we are at the point where we need to seek a new approach in which we can help novices to develop their own competence.

Problem-Based Learning (PBL) is aimed at promoting novices' autonomy and self-reflective actions which are required in a professional practice when they face problems and challenging situations. While PBL is now commonly employed in such areas, there has as yet been no significant movement to introduce this approach in the area of translator education.

This paper consists of three major components. First of all, the problems of educator-centred teaching in translation will be discussed. This will be followed by an outline of the benefits of PBL for translator education, from both theoretical and practical perspectives. The feasibility of PBL as an effective model for translator education will be then considered based on empirical case studies.

\section{MOTS-CLÉS/KEYWORDS}

translator education, problem-based learning, pedagogical approach, competence

\section{Introduction}

Various topics in the area of translation study, including equivalence, processes of translation and the use of genre-based approaches, have been discussed in the existing literature but there seems to have been insufficient focus on the question of how translator education can best facilitate the evolution from a novice translator to an expert translator. As Kiraly (2000) points out, the "transmissionist approach" appears currently to be the mainstream pedagogical approach in the domain of translator education. In this form of learning, a teacher (who is usually an expert 
translator) provides a mere "answer" which the teacher then expects the novices to internalise as knowledge, or learners ask questions and also expect categorical answers from the teacher. Thus, it can be said that the teacher in this approach acts as an instructor. While this method could be beneficial to both the teacher and learners from a class management perspective where there are large numbers of learners, this way of learning could leave the learners with some problems. The first problem is that the "answers" provided by the teacher, which may contain no other possible options, can leave the learners with a limited idea of the applicability of these answers to other contexts. While the "answer" can be used in the exactly same text, it is not likely that the learners will ever come across the exactly the same text or context again. Another problem is that if this approach expects the learners to memorise the answers given by the teacher without providing sufficient information about the processes involved in reaching the decision, it is likely that the learner will not have sufficient access to the underlying reasons for the choice which the teacher made.

\section{Evolution from Novice to Expert}

Before considering a new learning approach which could enable learners to develop their competences in translation to the pathway to an expert, a clarification of the definition of "expert" is necessary. There have been a significant number of attempts to define "an expert" or "expertise" in various areas, including language teaching, medical practice and psychology. It, however, appears that there is no consistent definition to date. As Tsui (2003) points out, precisely what separates an "expert" from "novice" has yet to be determined. While discrimination between the above two may be made by measuring one's ability through an examination leading to an accreditation, as can be seen from the example of NAATI (National Accreditation Authority for Translators and Interpreters) in Australia, it is, at least to some degree, doubtful whether the accreditation as such automatically means that a person is an expert. This is because of the fact 
that this kind of quality assessment is based on the individual's one-off ability in a limited context, disregarding the decision-making processes which underpin the professional choices and judgements made by the individual in question.

Definitions of expertise, however, tend to encompass the elements of highly advanced abilities and skills. Characteristics of an expert stated by both Leinhardt (1989 from Tsui 2003:53) and Sequimot (1988: 99) include the ability to integrate knowledge with one's highly-developed self-discipline, and these appear to be common characteristics of an expert in related literature.

These definitions can be made more explicit by considering the comparison between a novice and an expert. Various models which illustrate these differences have been proposed in a number of areas including teaching, medicine and nursing. Dreyfus \& Dreyfus (1986) developed a model of skill acquisition by dividing the level of evolution into 5 stages based on the ways in which experts make decisions and take actions, and place emphasis on "intuitiveness" as a distinctive characteristic which could be used to draw a line between the novice and expert. They also assert that the difference between a novice and an expert is that the expert can make a judgement based on their existing experience. Their model, however, has been questioned by other scholars on the grounds that it does not appear to take into account the variation of conscious and unconscious decision-making depending on the nature of task also does not incorporate the element of self-regulation. As Tsui (2003) points out, a novice cannot evolve in terms of competence only by accumulating experiences alone. Thus, the development of skills and competence in combination with how one reflects on experiences for future cases is crucial for this evolution. Without this, it appears that mere passive reception which accumulates in the form of experiences would not result in evolution.

Another model is that of Glaser and Chi's model (1988), which adopts a cognitive psychological approach and puts emphasis on a close connection between expertise and cognitive processes. Rather than establishing various level of expertise, their model focuses on the kinds of ability and capability that experts possess. The model asserts that experts tend to internalise deep 
knowledge of their specialised area(s) and experiences which they can organise to solve problems in more systematic and self-regulatory ways. Berliner's (2001) model focuses on teaching and the extent to which teachers actions are delivered flexibly and efficiently. Berliner argues the importance of expert teachers recall their previous experiences that are similar to those that they currently face. Thus, it can be said that Berliner's standpoint includes both intuitiveness as well as self-reflection. Finally, Marchionini's (1995: 11-12) model known as Personal Information Infrastructure (PII) model focuses on novice's and expert's individual interacting perspectives and includes general cognitive skills and specific cognitive skills. As can be seen from the above models, attempts to distinguish the "novice" from the "expert" yield the following common observations:

1. experts solve problems in an intuitive manner on the basis of experience;

2. expertise evolves as one regulates one's behaviour and skills.

Based on the above two points, it is worth examining how these likely elements encompassed in an expert have been discussed in previous literature in order to investigate the principles which underpin the evolutionary pathway from novice to expert. This is then discussed in relation to the context of translation.

The issue of problem solving has been discussed in a way that it is considered as an indispensable element of the evolution of expertise in a significant number of studies including Rollet (1998), Bawden (1987), Luconi and Tabatabai (1999), Tsui (2003), Glaser and Chi (1998) and Bereither and Scardamalia (2003). One view that the above literature posits in common is that an expert who has experienced an evolution from a novice has faced various problems and has had to deal with them. Moreover, it is noticeable that there is a distinctive difference in the way that an expert deals with problems, compared with those who are regarded as novices. As Rollett (2001) asserts, experts are considered to have experienced a wide range of "resolved situations" (2001: 38). These situations are described as the base of expert teachers' rich knowledge from the pedagogical and psychological perspectives, and represent previously "unresolved situations" 
where the teachers faced difficulties but resolved them in a successful and smooth manner. According to Rollet, an expert, then, tends to employ a "positive feedback loop" (2001: 38) in order to deal with problems of a similar nature to what they have faced in the past. There is another perspective from which problem-solving is observed, which concerns the differences in the ways in which an expert deals with a problem, as opposed to the way in which a novice does so. As Bereither and Schardamalia (2003) argue, the way experts approach problems is not simply to solve them but to attempt to internalise and make use of them so as to increase their expertise. This concept appears to coincide with Tsui (2001) in that experts can problematise what appears to be routine and deal with it. On the issue of problem-solving, Luconi and Tabatabai (1999) find from their empirical study on information search skills based on Marchionini's (1995) model that differences between experts and novices are evident in the area of navigational strategies and systematised knowledge in which new information is integrated with prior knowledge. Similar findings can be found in other studies including Hill and Hannafin (1997) and Rumpradit (1998). Having discussed models of and perspectives on the notion of expertise and the distinction between a novice and an expert, we now need to examine the relevance of the above literature to the context of translation. It can be said that a translator, as a practitioner of a professional occupation, is in the position where he or she is likely to face new challenges. This characteristic could particularly be evident from the fact that their translation jobs are not the same from the perspective of their areas (e.g. medical, legal, literary), registers and genres of the texts (e.g. case reports, business contracts, journal articles, tourism brochures). Thus, it can be said that expert translators require cognitive skills, knowledge and experiences in order to construct their decisions and strategies to deal with novel challenges. While there have been a significant number of both theoretical and empirical studies in the quest for the key distinguishing standards between novices and experts in other areas as mentioned above, it appears that there have been remarkably few such studies in the area of translation. It appears therefore that investigating the relevance of the existing models and findings to the context of translation is necessary, from the perspective of both 
novice-expert differences and their application to pedagogical approaches suitable for translator education.

\section{Problem-Solving as a Core Skill for an Expert Translator}

If we assume that the way one deals with a problem is one of the points of departure for distinguishing an expert from a novice, it follows that translator education would benefit form the incorporations of problem-solving in order to bridge gaps between a novice and an expert. Thus, it is sensible to employ a pedagogical approach for novice translators in which solving problems is the central focus. As Vygotsky (1987) points out, in addition to opportunities for problem-solving, some kind of "guidance" provided by those at a higher level of expertise, including teachers and more senior peers, is essential in order to enable the evolution of a novice towards an expert. Problem-Based Learning (PBL) then emerges as a potential approach through which such evolution can be achieved. A discussion of the defining characteristics of PBL is also required in order to consider the applicability of this approach to translator education.

PBL was originally developed in the area of medical education in which student practitioners were seeking to acquire practical knowledge and skills that they would need in clinical practice. Health-related courses at McMaster University in 1980s (Barrows and Tamblyn, 1980) were some of the earliest examples of courses in which PBL approaches were applied. Since then, this approach has been introduced in wider range of fields including teacher education programs (So, Yeung, Lo and Volk, 2001), learning programs on investment (Tang \& Mak, 2001), and real estate studies (Raftrey, Cheung, Chiang, Yeung \& Ma, 2001). While PBL may have been part of translator education curricula in the past, there has been no study at all which takes up the issue of the appropriateness of PBL in this particular educational context.

Existing literature suggests that PBL-based curricula appear to encompass four main characteristics in common. First of all, learners are faced with a "problem" as Barrows and 
Tamblyn (1980), Forgarty (1997), and Woods (1994) point out. This can be considered as the central feature of this approach, and the "problem" needs to be one that is "relatively challenging" (Forgarty 1997 and Boud 1987) at the learners' current level. In most of the cases described in previous studies, there tends to be one major problem which is underpinned by a number of sub-problems. The second characteristic of the Problem-Based Learning approach is the authenticity of the problem at hand, as the aim of this approach is, of course, to provide learners with the opportunity to solve a problem in a real-life context. Increased learner autonomy is the third feature of the approach. As Schwartz, Mennin and Webb (2001) noted, learners are likely to take active steps that are required for solving the problem. This results in, as the last characteristic, a teacher who no longer acts as an instructor who provides an answer, but as a facilitator whose role is to provide appropriate scaffolding for the learners, as Boud (1987) points out.

Having clarified the major characteristics of PBL, it is then necessary to understand the sequence of learning in this approach. While there are some minor variations the elements of this sequence as it is described in the research literature, including Kolb (1984), Lewin (1951) and Barrows \& Tanblyn (1980), the sequence presented in the Diagram 1 appears to be common among them. As indicated in the diagram, the focus lies on the analysis of the problem which then requires learners to explicate their existing knowledge which is relevant to solving the problem and knowledge with which they have not been equipped. These actions are then followed by the learners' implementation of search for unknown knowledge through both individual and group study towards the acquisition of non-existing knowledge and the integration of their existing and newly acquired knowledge towards a solution. It should also be noted that one cycle of this sequence does not necessarily mean the end of the entire action but it is possible that this cycle of action is repeated in the same way with some improvements, if learners find the refinement and elaboration necessary. 


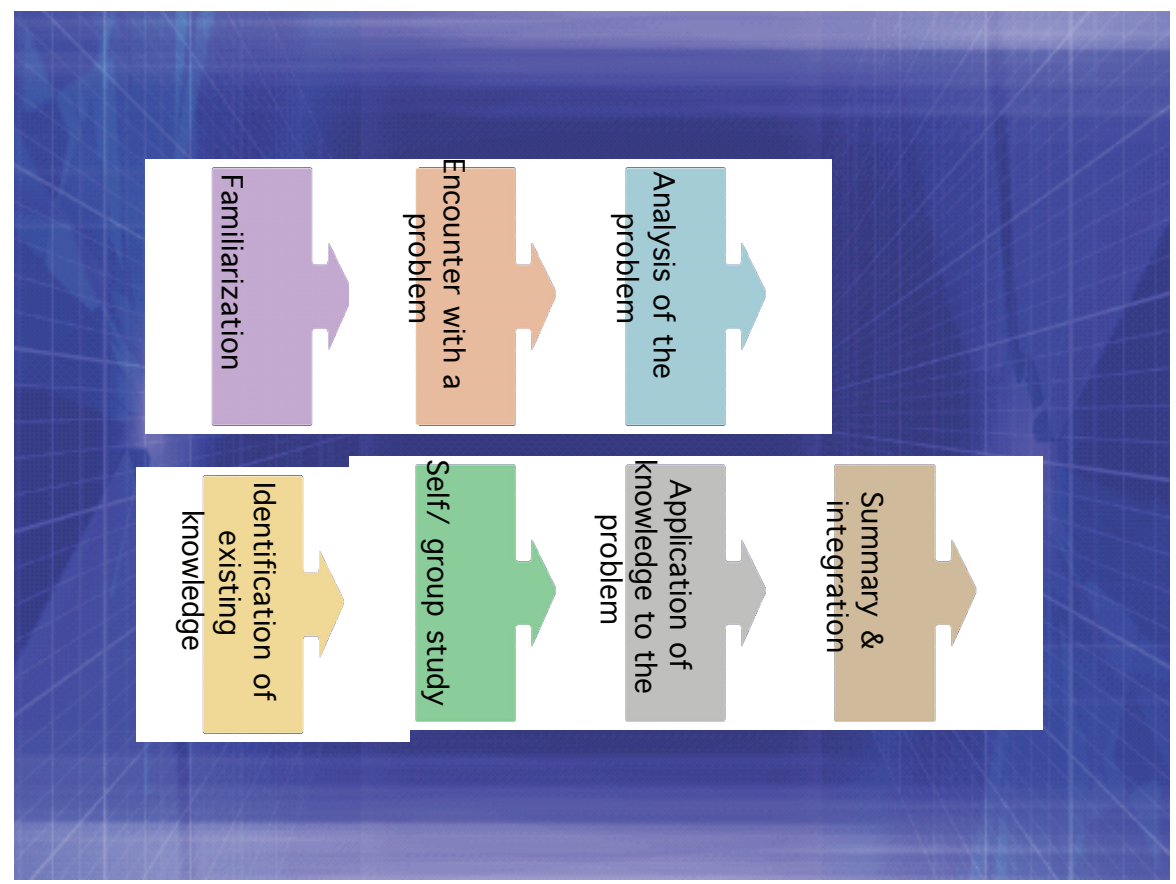

Figure 1. An empirical study - Application of PBL to translator education

\section{Methodology}

Having discussed some of the key facets of Problem-Based Learning which are relevant to the broad goals of translator education as well as its potential value in this field, there is clearly a need for empirical investigation of the applicability of PBL to translator education. The following section provides a description and discussion of a pilot study which was carried out in late March, 2005. 


\subsection{Research Questions}

a) Can PBL be applied to translator education?

b) How do Japanese novice translators perceive PBL?

\subsection{Participants}

Nine Japanese students in their final semester (i.e. $3^{\text {rd }}$ semester) in MA in Translation and Interpreting Program in an Australian university volunteered to take part in this pilot study. The reason for focusing on the students in their final semester is that they have experienced the period of "scaffolding" in the previous two semesters. Thus, it is clearer to myself as the teacher and researcher what kind of existing knowledge they have acquired and what kind of knowledge they are not likely to have been explored.

\subsection{Procedure}

The core structure of this empirical study is based on the above-mentioned common sequence of action in PBL. At the initial stage, the explanations about the rationales and procedure of this time's learning activity were provided to the participants. This was then followed by the presentation of the problem:

"You have been asked to translate an article on digestive-related diseases in a medical journal. This translation job first requires you to conduct research to obtain necessary fundamental information prior to beginning the translation."

The subjects were then asked to form groups of 2 or 3 and initiate their discussion of how to go about this problem. As mentioned in the literature review above, one of the salient characteristics of PBL is its open-ended nature in terms of outcomes and its heavy emphasis on learner autonomy. This is why this empirical study attempted to leave the process and approaches of their learning with the participants. This study consisted of two cycles of activity which lasted for a total of two weeks. Each cycle ran for one week in which the participants were to work on 
solving the given problem both as a group and as individuals. They were thus expected to commit themselves during the time to group work as well as individual work at home. During this process, a KND chart (see Appendix 1) was distributed to both individual subject and each group; the aim was to provide them with clearer idea of their existing knowledge and unknown knowledge. After the two activity cycles had been completed, the participants as groups were required to make presentations. In these presentations, the subjects were expected to include their solution(s), their existing and unknown knowledge, and the process of solving the problem. Finally, the subjects were given a questionnaire to fill out (see Appendix 2).The aim of this questionnaire was to draw out their perceptions on the second research question set out above.

\section{Findings}

\subsection{KND Chart}

As mentioned in the previous section, a KND chart enables the researcher as well as the subjects to identify the subjects' existing knowledge and unknown knowledge, which is necessary if one wishes to investigate correlations between this knowledge and the ways they address the problem. Firstly, the majority of the participants identified that they had already had knowledge of the fundamental functions of the organs which are considered to be part of human digestive system (see Figure 2). Some of them also had pre-existing knowledge of the names and locations of the organs. It can be said that this result illustrates that individuals in a group could possess same or different extents of pre-existing knowledge and experience in the chosen area. This can be a good point of departure for enabling learners to realise beneficial aspect of PBL in which learners are likely to encounter the rich variation of pre-existing knowledge which other individuals possess. 
Figure 2 Existing knowledge

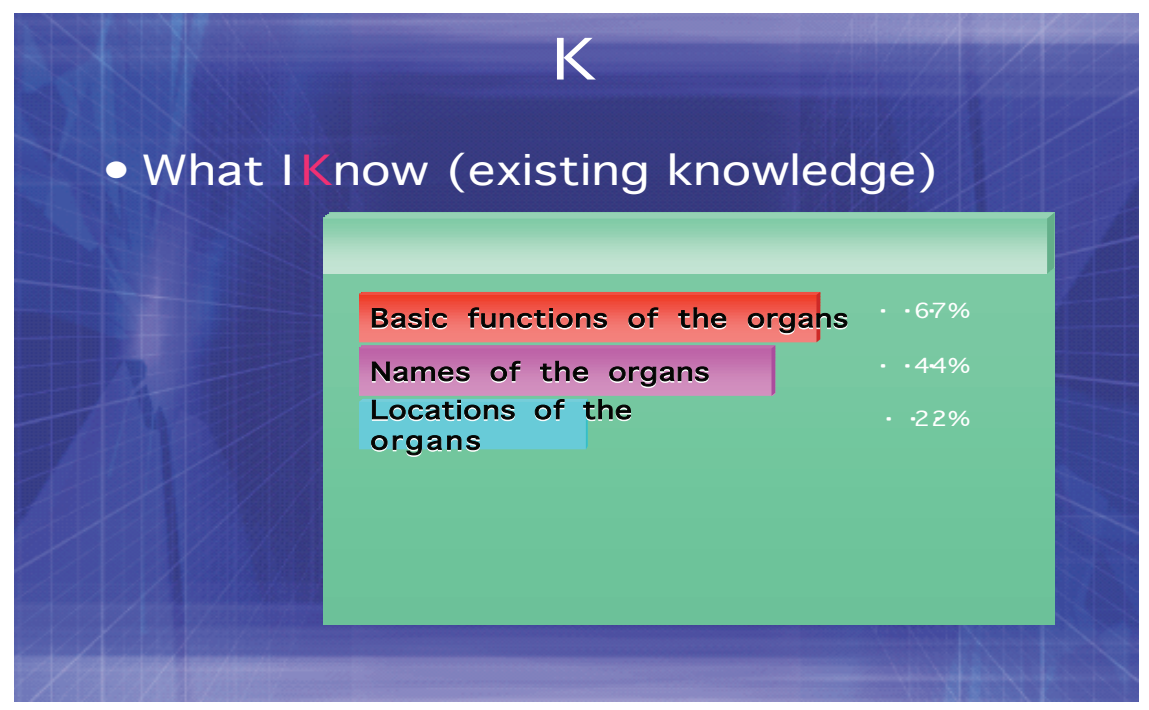

As opposed to the findings in " $\mathrm{K}$ ", many of the participants acknowledged their lack of specific knowledge of the functions the relevant organs and/or component parts of these organs encompass. It should also be noted that some noticed the necessity of establishing knowledge in terms of register and lexical choice which texts in the area employ.

Figure 3. Unknown Knowledge

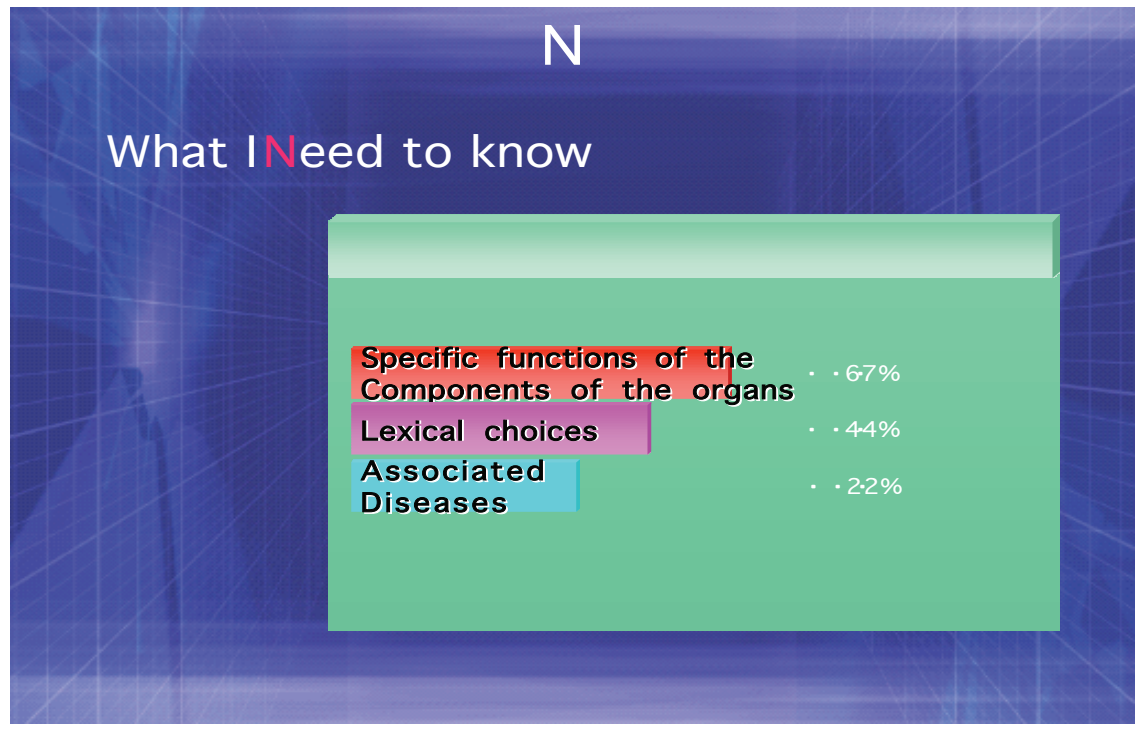


The final stage where the subjects were required to identify their actions based on their existing and unknown knowledge indicates that their focus here is rather strategic and involves procedural actions which are directly linked to problem-solving. This may be explained by the fact that these participants have spent significant amounts of time and effort carrying out research for their regular translation practices in the previous two semesters of their studies.

Figure 4 Necessary actions

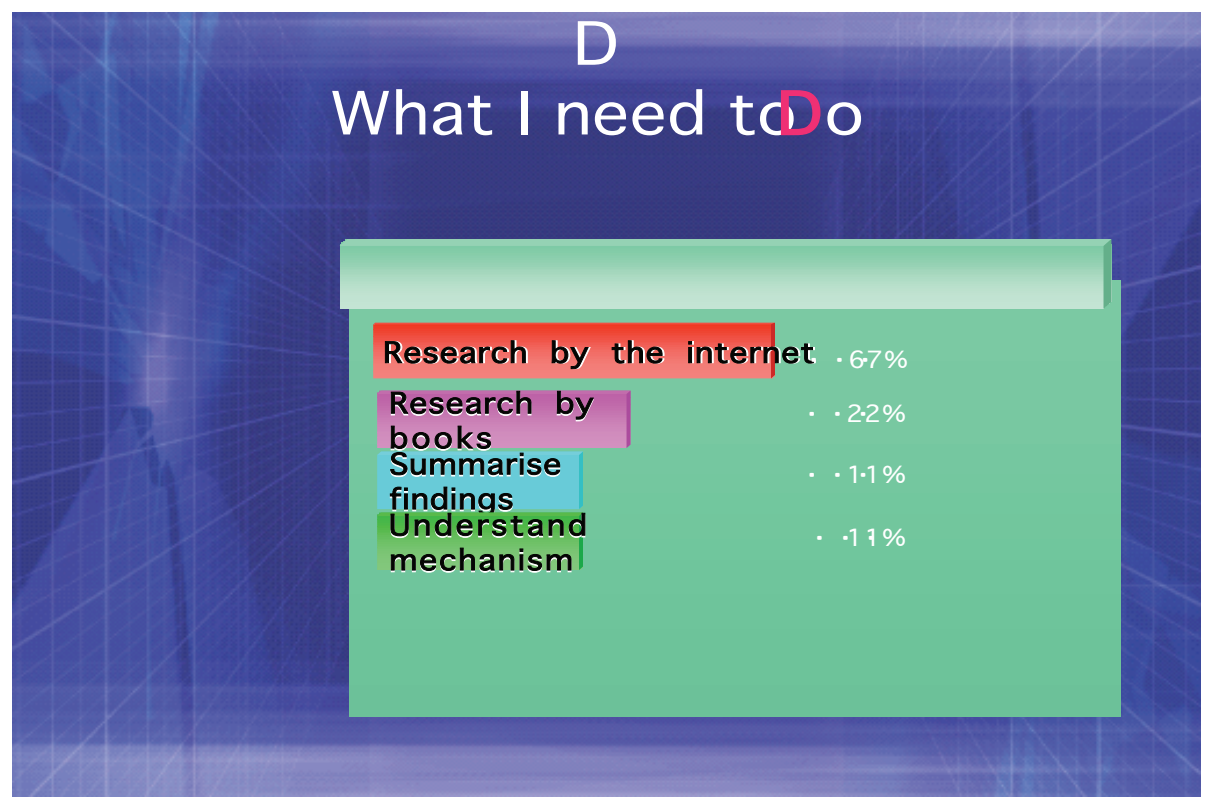

As can be seen from the findings in the KND chart, it is appeared that the chart enables learners to clarify their existing and new knowledge, and the ways in which this influences the actions they take in attempting to address the problem to be solved. 


\subsection{Learner Perceptions of PBL}

The findings in this section attempt to answer the first research question: "Can PBL be applied to translator education?". In the post-task questionnaire, the participants were first asked to choose one of the five degrees of agreement (i.e. strongly agree, agree, neutral, disagree and strongly disagree) in relation to five statements, which aimed to determine their learning preferences in relation to PBL. As can be seen from the results (see figure 5), the majority of the participants indicated a preference for problem based learning over a transmissionist approach, and recognised the values of PBL in terms of its usefulness for solving problems with peer collaborations and connection with their future career as expert translators. There were no negative comments about the use of PBL in translator education.

Figure 5. Learner perceptions of PBL

\section{Learner perceptions of PBL}

I prefer this method to a lecture style 4:2 useful for solving the problem Employed method will be useful in the future Thoughts and suggestions by peers Contributed to solve the problem. The workload of this activity was heavy $\cdot 2: 4$

When asked further about what aspects of PBL they liked most (in an open-ended question), many participants indicated in their responses that PBL is perceived positively from the perspectives 
of its direct linkage with their learning aims to be a professional translator. The participants' positive thoughts in relation to the approach also extend to its nature, which they believe enables them to obtain the knowledge necessary in order to undertake translation jobs when they notice that they lack fundamental knowledge of the area they need to know for accomplishing their translation jobs. Similar number of the participants, as in the previous comment, points out that PBL helps the novices to develop their knowledge through activities in the approach in a manner that other group members' thoughts and knowledge enrich the effectiveness of their problem-solving processes and outcomes. As can be seen from these results, it appears that PBL is widely accepted by the entire group of the participants on the grounds that PBL allows novice translators to experience knowledge-building opportunities in a realistic setting with peer cooperation and to gain insights which are reflected in their actions.

\section{Conclusion}

In this paper, the differences between a novice and an expert, and the elements which are likely to underpin the evolutionary pathway from a novice to an expert were first discussed. An examination of the existing literature in this area reveals that the notion of "problem-solving" is considered to play a central role in the evolution of an individual's level of expertise from that of a novice to that which is characteristic of an expert. Given the fact that the mainstream pedagogical approach which is currently used in translator education is one in which a translation teacher provides a package of information to novices, a clear lack of opportunities and directed efforts towards bridging the gaps between a novice and an expert is evident. The employment of novel pedagogical approaches which can fill these gaps is, therefore, indispensable in order to provide a sound educational framework in this area. The potential advantages of Problem-Based Learning (already an established approach in a growing number of other fields) as a novel approach in translator education have been outlined. The attempts which were made in the present pilot study 
focus on investigating the extent to which PBL is applicable in the area of translator teaching, and the perceptions of a cohort of novice translators who were required to undertake activities which are consistent with the nature of PBL. While it should be admitted that the findings in this pilot study have limitations due to the constraints of the participant number, the findings do offer some preliminary evidence that PBL with sound scaffolding provided by a teacher can promote learner autonomy amongst novice translators enrolled in a postgraduate degree program in translation studies. This then seems to develop learners" "learning how to learn" skills which ought to be critical for translators who are required facing with a wide range of problems. Another critical point which is arisen from this study is the authenticity of tasks in PBL teaching and learning in the area of translation. This was determined by the fact that the chosen task of this study was a problem with which myself, as a translator, faced in the past when engaging in an actual translation job. This element of PBL allows novices to develop their skills and knowledge in a manner as if they were in authentic situations. It can, thus, be easier for novices to apply the problem-solving processes to the situations with which they face in reality once they become expert translators. While there was a concern prior to this pilot study that the novices may find significant gaps of learning methods between PBL and with which they had been familiar, it appears that the subjects perceived PBL in a positive light. It can, thus, be said that PBL possesses considerable potential in translator education to facilitate the acquisition of knowledge and skills by novice translators who aspire to join the ranks of those who are experts in the field.

Following from this pilot study, a number of recommendations for further study can be made. First, a larger-scale study is necessary to investigate the extent to which PBL is acceptable to translator educator and novice translators in the context of translator education. Moreover, it is necessary to carry out a longitudinal action research study in order to monitor and investigate the correlations between the evolution of expertise and the extent to which PBL can contribute. Finally, careful consideration of the way of selecting problems for PBL needs to be undertaken. This is because of the fact that the selection of problems can be based on investigator perception, 
which may not be appropriate in all situations due to its subjective nature. This issue can be addressed by conducting retrospective-narratives with novices and experts so that the problems and their problem-solving processes which they previously encountered through their trainings and professional practice can be analysed with the assistance of qualitative analysis software.

\section{RÉFÉRENCES}

Barrows, H. and R. TAmblyn (1980): Problem-Based Learning: An Approach to Medical Education, New York, Springer.

BARROWS, H.S. (1986): “A taxonomy of problem-based learning methods”, Medical Education 20, p. 481-486.

BERLINER, D. (2001): “Teacher expertise”, in BANK, F and A. S. MAYES (eds.): Early Professional Development for Teachers, London, David Fulton Publishers.

Boud, D. (ed.) (1987): Problem-Based Learning in Education for the Professions, Kensington, HERDSA.

Boud, D. (1987): "Problem-Based Learning in Perspective", in Boud, D. (ed.): Problem-Based Learning in Education for the Professions, Kensington, HERDSA.

Chi, M. T. H., P. J. Feltovitch and R. Glaser (1981): "Categorization and representation of physics problems by experts and novices", Cognitive Science 5, p. 121-152.

Fogarty, R. (1997): Problem-Based Learning and Other Curriculum Models for the Multiple Intelligences

Classroom, Melbourne, Hawker Brownlow Education.

HILl, J. R. and M. J. HANNAFIN (1997): “Cognitive strategies and learning from the WWW”, Educational Technology Research and development 45-4, p. 37-64.

KIRALY, D. (2000): A Social Constructivist Approach to Translator Education: empowerment from theory to practice, Manchester, Northampton, St. Jerome Pub.

KolB, D. (1984): Experiential Learning: Experience as the Source of Learning and Development, New Jersey, Prentice-Hall Inc. 
LEWIN, K. (1951): Field Theory in Social Sciences, New York, Harper \& Row.

LuConi, F and D. TAB ATABAi (1999): Searching the Web: Expert-Novice Differences in a Problem Solving Context, Quebec, The Educational Resources Information Center.

MARCHIONINI, G. (1995): “Information seeking in electronic environments. Cambridge series on Human-computer models", International Journal of Man-Machines Studies 30, p. 591-618.

Raftery, J. J., A. A. C. Cheung, Y. H. Chiang, C. W. Stanleyy and F. M. F. Ma (2001): "The Student Experience of Problem-based Learning in Real Estate Studies”, in KEMBER, D., S. CANDLIN and L. YAN (eds.): Further case studies of improving teaching and learning from the Action Learning Project, Hong Kong, Action Learning Project.

RUMPRADIT, C. (1998): From novices to experts: User Performance, confidence and satisfaction on the World Wide Web, Baltimore, Association of Information Systems.

SEguinot, C. (1998): "Knowledge, expertise, and theory in translation", in CHESTERMAN, A. et al. (ed.):

Translation in Context, Amsterdam/Philadelphia, John Benjamins Publishing company.

So, K. S., K. H. Yeung, T. K. Albert and K. VolK (2001): “Introducing Problem-Based Learning to Teacher Education Programmes", in KEMBER, D., S. CANDLIN and L. YAN (eds.): Further case studies of improving teaching and learning from the Action Learning Project, Hong Kong, Action Learning Project.

StePien, W. and S. GALlaGHER (1993): "Problem-based learning: As authentic as it gets", Educational Leadership, April, p.25-28.

TANG, G. Y. N. and B. S. C. MAK (2001): "Learning Investment through Simulated Practical Experience”, in KEMBER, D., S. CANDLIN and L. YAN (eds.): Further case studies of improving teaching and learning from the Action Learning Project, Hong Kong, Action Learning Project.

Tsui, A. (2003): Understanding Expertise in Teaching: case studies of second language teachers, Cambridge, New York, Cambridge University Press.

Vytotsky, L. S. (1987): Mind in Society: The development of the higher psychological processes, Cambridge, MIT Press.

Woods, D. R. (1994): Problem-based Learning: How to Gain the Most from PBL, Waterdown, Donald. R. Woods. 


\section{APPENDIX 1}

KND chart (adapted from Fogarty, 1997 and Stepien et al., 1993

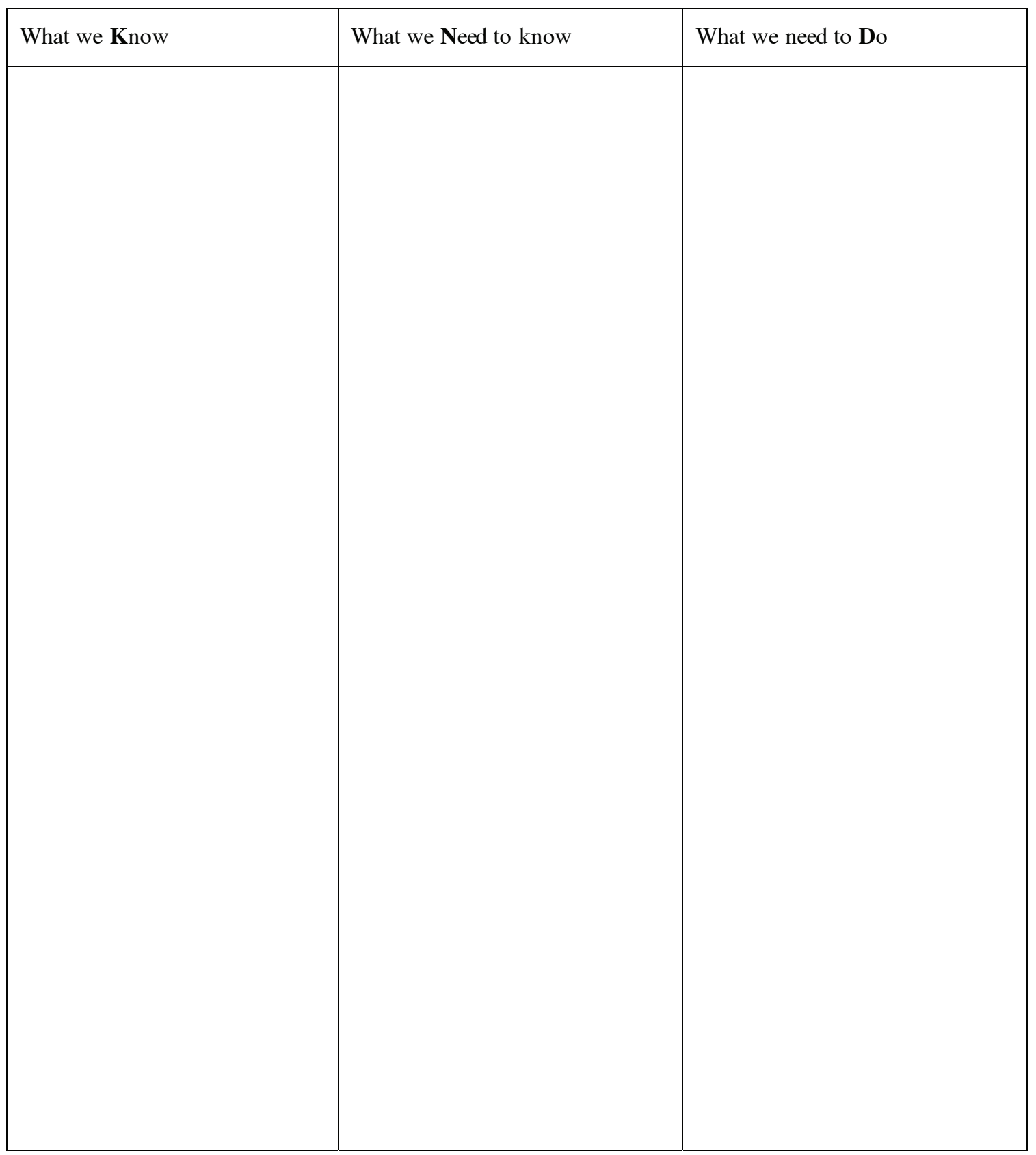




\begin{tabular}{|l|l|l|}
\hline & & \\
\hline
\end{tabular}

\section{APPENDIX 2}

\section{Questionnaire}

This questionnaire aims to investigate your perceptions of the PBL activities.

A. Please circle one of the provided choices which reflects MOST on your perceptions of the given statement.

1. The activity was useful for solving the problem.

Strongly agree Agree Neutral Disagree Strongly disagree

2. The problem-solving methods you employed will be useful for future translating actions.

Strongly agree $\quad$ Agree Neutral Disagree Strongly disagree

3. Thoughts and suggestions from your group member(s) contributed to solving the problem.

Strongly agree $\quad$ Agree Neutral Disagree Strongly disagree

4. The workload of this activity was heavy.

Strongly agree $\quad$ Agree Neutral Disagree Strongly disagree

5. I prefer this method to a method in which a lecture-style is used.

Strongly agree $\quad$ Agree Neutral Disagree $\quad$ Strongly disagree 
B. Please comment freely on the following questions

1. What did you like MOST with this activity? Why?

2. What did you like LEAST with this activity? Why? 